\title{
Revisiting tropes of environmental and social change in Casamance, Senegal
}

(Forthcoming 2016 in Højbjerg, C., Knörr, J. and Murphy, W. (eds) Politics and policies in Upper Guinea Coast societies: change and continuity. Palgrave Macmillan.)

\section{Martin Evans}

University of Chester, Department of Geography and International Development, Parkgate Road, Chester CH1 4BJ, UK

Email: $\underline{\text { m.evans@ } @ \text { chester.ac.uk }}$

\begin{abstract}
Established tropes hold that reduced rainfall across the West African Sahel and savanna from the late 1960s onwards caused migration from rural areas to cities or to better-watered lands further south. It is argued that this in turn caused major shifts in the rural economy, social transformation, disputes over land tenure and use between indigenous and immigrant populations, and violent conflict in places. Alternative analyses, while recognising a role for environmental change in social processes, take a deeper historical perspective and offer a more diverse, nuanced view of causality. This debate is worth revisiting to help prevent flawed, sometimes fallacious tropes from informing development policy and practice. The chapter thus examines paddy rice cultivation in Casamance, southern Senegal, amid broader contemporary contestations about environmentally-induced migration.
\end{abstract}




\section{Introduction}

In the past couple of decades, tropes about the nature, causes and consequences of environmental change in sub-Saharan Africa and elsewhere have been challenged (e.g. Fairhead and Leach 1996, 1998; Leach and Mearns 1996; Stott and Sullivan 2000). Some of this work has taken a 'political ecology' perspective, broadly defined, rooted in a poststructuralist view that scientific knowledge is not neutral and that its creation takes place within particular political contexts. Historical examples are cited from the colonial period onwards where particular (mis)readings of landscape processes, underpinned by flawed science, have been used as a basis to exercise power over particular groups or to justify development interventions (Fairhead and Leach 1996; Leach and Mearns 1996). The losers in such dynamics tend to be rural people, who often know their landscape best (if not in modern, scientific terms) but whose needs are not properly understood or supported, or who become subject to restrictions on long-standing agricultural activities. Misplaced development policies, which sometimes subtly try to engineer social as well as environmental change, are imposed on them, wasting limited resources to little useful effect. At worst, tropes of environmental change are used as an opportunity to relocate people or as a cover for dubious or repressive political projects.

One key battleground for such debates has been the West African Sahel and its edges: its complex, ever-shifting border with the Sahara desert to the north and its gradation into woody savannas and ultimately the forest belt going south. Recent decades have seen reduced rainfall and associated environmental change (including desertification) and evolution of different agricultural production systems, generating among researchers and policymakers new contestations about the meanings, benefits and costs of such changes. In some cases these contestations rehearse longer-standing debates about people's relationship with the landscape 
that date back to British and French colonial times (Swift 1996). At the same time, they speak to very contemporary concerns about environmental change in a warming world and its feared social and political consequences.

The chapter considers these debates as they apply to Casamance, Senegal's southern limb, sandwiched between The Gambia and Guinea-Bissau. Historically an important area for lowland (paddy) rice cultivation, Casamance is situated to the south of the Sahel in an area of woody savannas. The focus here is mainly on Lower Casamance, the western part of Casamance and administratively now defined as Ziguinchor region, named for its capital city. Much of the landscape of Lower Casamance is dominated by the Casamance River and its delta. The region largely comprises sandy plateaux and ridges broken up by a network of alluvial valleys with richer, clayey soils. Some valleys are fed only by highly seasonal rainwater but many others are in addition fed by perennial tidal tributaries and backwaters of the Casamance River (Linares de Sapir 1971; Pélissier 1983). In this complex, deltaic environment, paddy rice cultivation requires sophisticated and labour-intensive hydrological management, particularly the control of water flows during the rainy season. The construction and careful use of dykes and sluices is all that keeps salinity sufficiently low for rice, even more salt-tolerant varieties, to grow in many lowlands, and allows some brackish mangrove sites to be reclaimed for cultivation. This is, as Baker (2000) highlights, 'an environmental balancing act' and the agro-ecological system described is sensitive to variability in rainfall amounts and timing within and between years.

The discussion begins by considering two versions of the history of recent decades that underlie different tropes about the relationship between environmental and social change. One is premised on the view that 'agro-ecological collapse', at least of paddy rice cultivation, has driven outmigration; the other takes a more nuanced, longer-term view of agrarian change in the region. The chapter moves on to consider why the former trope continues to carry some 
weight in development thinking in spite of clear evidence challenging it; while it contains some elements of truth, it is characterised here as a fallacy overall. The chapter ends by examining the significance of such debates in the context of renewed discussion about environmentally-induced migration.

\section{Two Versions of History, Two Tropes}

\section{Drought, outmigration and agrarian change in West Africa}

The starting point for the first trope is clear in the recent historical record. In 1968, a drier period began across the West African Sahel and savanna that, despite occasional wetter years (particularly since the turn of the millennium), apparently continues (Grainger 1990; Hulme 1999). Various authors have noted that identifying 'drought' (in the sense of an abnormally dry period) in the Sahel is problematic, given inherently large temporal and spatial variability in rainfall and inadequate long-term records (Agnew and Anderson 1992; Baker 2000; Hulme 1999). The term is, however, used here as shorthand for what is recorded and locally perceived as generally reduced rainfall over the past nearly-five decades.

The literature records various social consequences of the drought. With established agro-ecological systems no longer providing a sustainable living because of reduced crop yields and livestock mortality, it is argued, rural people have sought alternative forms of livelihood. They have turned to other forms of production or to non-agricultural activities artisanal or low-skilled urban jobs, or trade - either in situ in rural areas or, for many, through migration to cities in the region in the quest for work. The populations of cities such as Dakar, Saint-Louis, Niamey, Ouagadougou and Bamako have swelled partly as a result of this ruralurban migration, which was particularly high in the early years of the drought in the 1970s. 
Others have headed south, following the more or less north-to-south gradient of increasing mean annual rainfall between the Sahel and the Lower Guinea Coast, seeking better-watered lands where they could continue to farm. In some rural areas receiving these southbound migrants, conflicts - sometimes violent - have occasionally flared up as 'autochthones' and immigrants have found themselves competing for the same resources such as land and forests (Reuveny 2007). The overall effect on communities affected by the drought, it is claimed, has been greater livelihood diversification. This has taken place within a broader restructuring of socio-economic relationships between city and countryside, mediated to a large extent through remittances and other forms of economic exchange within the extended family (Fall 1998).

Lower Casamance presents, at first sight, a familiar case study in the context of the drought. The meteorological record and local perceptions indicate significantly reduced rainfall for the period in question compared with earlier totals (table 1).

\begin{tabular}{|l|l|}
\hline Period & $\begin{array}{l}\text { Mean annual rainfall, } \\
\text { Ziguinchor }(\mathbf{m m})\end{array}$ \\
\hline $1927-47$ & 1561 \\
\hline $1947-67$ & 1587 \\
\hline $1967-87$ & 1187 \\
\hline $1990-2000$ & $1212^{*}$ \\
\hline
\end{tabular}

Table 1: Ziguinchor rainfall, 1927-2000

Sources: AJAC-APRAN 2001; Cormier-Salem 1989

* Figure for Niaguis, $11 \mathrm{~km}$ east of Ziguinchor

The figures show a drop in annual rainfall of some $400 \mathrm{~mm}$ in the drought period compared with previously. It is not clear, though, to what extent this has been accompanied by a shortening of the wet season. Cormier-Salem (1989) claims that its duration has fallen from five to three months but its mean length in the 1990-2000 period was 139 days (author's 
calculation from figures in AJAC-APRAN 2001) - just over four-and-a-half months. The distribution of rainfall within the wet season may also, however, be a factor influencing local perceptions here.

Whatever the detail, paddy rice cultivation has undoubtedly suffered as a result of reduced rainfall. Here as elsewhere along the Upper Guinea Coast, the effects of drought on lowland agriculture have been mediated principally through incursion of saline water from the Atlantic further up the Coast's rivers (such as the Gambia, Casamance and Cacheu). Previously, more abundant rainfall kept such water well downstream through higher wetseason floods and higher dry-season river levels. With the drought, Baker (2000) notes that saline water is now found some $200 \mathrm{~km}$ upstream from the mouth of the Gambia River in the dry season, and over $100 \mathrm{~km}$ even in the wet season. Saline water penetrates at least as far along the Casamance River (Dieng 1999) and thence up its tributaries and backwaters, with the same consequences: the further salinisation, via irrigation or groundwater, of many paddies in Lower Casamance, reducing or totally preventing rice production. In Senegal as a whole, lowland rice production fell by $40 \%$ between 1975-76 and 1995-96 (Cruise O’Brien, Diop and Diouf 2002).

Lower Casamance has also seen rural depopulation during the period of the drought, as detailed later, with large-scale outmigration of many Casamançais to Dakar or other urban areas in northern Senegal or The Gambia. It is therefore relatively easy to construct a simple trope of causality, with environmental change (drought and agricultural failure) driving social and economic change (outmigration and livelihood diversification away from agriculture). Certainly, all of the individual phenomena described - agro-ecological collapse, rural depopulation, livelihood change - are individually and objectively true. They have happened. But the relationships between them need closer attention to determine the true nature and direction of causality, as shown in a different reading of history. 


\section{Environmental variability, de-agrarianisation and social change in West Africa}

An alternative trope takes a longer view of the social and economic changes recounted above and it orders circumstances, drivers and effects differently in some cases. It does not deny that these changes took place but situates them more firmly and critically in their historical context. From a theoretical perspective, they can more usefully be understood as "“deagrarianisation" [which] is defined as a long-term process of occupational adjustment, income-earning reorientation, social identification and spatial relocation of rural dwellers away from strictly agricultural-based modes of livelihood' (Bryceson 2000, p. 1). The 'longterm' nature of shifts in livelihoods, mobility patterns and in society as a whole is now considered for the case of Lower Casamance.

Labour mobility is a long-established feature of the West African economy, pre-dating the Atlantic slave trade. But in the 20th century, the security imposed by colonial forces, the introduction of modern transport and the emergence of a free (i.e. wage) labour force greatly increased such mobility (Hopkins 1973). For Lower Casamance communities, this process continued from the colonial into the post-colonial era. Its history is briefly recounted here because of its critical bearing on livelihoods in the region, particularly among the Diola, the majority ethnic group there (Foucher 2002; Lambert 2002). Some Diola men and women had travelled to The Gambia to harvest forest products from the 1860s onwards (Linares 1992) but from around the turn of the 19th and 20th centuries, such seasonal agricultural migration expanded. Growing numbers of young Diola men, particularly those from north of the Casamance River, went to The Gambia to undertake groundnut cultivation and to harvest oil palm produce and wild rubber (Foucher 2002). Within Casamance too, significant seasonal rural-urban migration started at the end of the 19th century, when French companies began to 
hire Diola women, with their reputation for being able to carry heavy head-loads, to load and unload ships at Ziguinchor port and elsewhere along the Casamance River (Linares 1992). Such wage-labour migration by Diola women became well established early in the 20th century with as many as $1,500-2,000$ of them involved. Women were more generally used to accompanying their brothers as poorly-rewarded domestics on the men's seasonal agricultural migrations, usually to undertake groundnut cultivation elsewhere in Casamance.

This helped set the scene for longer-distance rural-urban migration by men and women from Lower Casamance to northern Senegal (Foucher 2002). This began in the 1930s but it was really after the Second World War that growing urban job opportunities through 'Africanisation' of the colonial administration and through army recruitment began to draw larger numbers of young men to Dakar, again particularly from among the Diola. The growth of urban salaried employment for men in turn created more independent job opportunities for Diola women. They worked in increasing numbers as paid housegirls or bonnes in Dakar (and Banjul), although again they had undertaken such trajectories on a small scale since the 1930s. They were initially limited by poor transport links, which enabled Diola men to try to restrict women's movements, but the completion of the Transgambian Highway (linking Ziguinchor to Dakar) in 1957 and the advent of economical daily bus services along it removed such obstacles. In the 1960s, then, economic migration to Dakar became increasingly general among young Diola adults of both sexes (Lambert 2002). Post-war demographic growth added to increasing competition for urban jobs: later male migrants had to seek work not just in public service but in the artisanal and industrial sectors; women continued to seek domestic employment and, they hoped, a salaried husband established in town (Lambert 2002). Economic overcentralisation on Dakar was (and remains) the overarching structural context of such migration: for example, Sar (1977) noted that Cap Vert (now Dakar) region, then home to $15 \%$ of Senegal's population, accounted for $66 \%$ of 
salaried workers including $42 \%$ of civil servants and $80 \%$ of employment in the industrial sector.

Macroeconomic decline, however, was to change mobility and livelihood patterns further. The late 1960s and 1970s saw declining groundnut production in Senegal, resulting from drought and the withdrawal of French subsidy, combine with the more general impacts of the OPEC oil shocks and deteriorating terms of trade (Cruise O'Brien, Diop and Diouf 2002). State wastage and mismanagement further exacerbated the situation of agricultural producers, accelerating rural-urban migration nationally. By 1979, economic deterioration led Senegal to accept a structural adjustment programme (SAP), one of the first countries in Africa to do so. In the 1980s, generous foreign aid mitigated the impacts of SAPs on the state, at least in its Dakar fastness, and consequently its need to reform. But in the 1990s, increased pressure from the World Bank and the International Monetary Fund forced greater state retrenchment and economic liberalisation (Cruise O'Brien, Diop and Diouf 2002). Decisive in the imposition of reform was the devaluation (by half) in 1994 of the CFA franc, the common currency of Senegal and most other Francophone West African states, reducing foreign buying power and having further damaging impacts on the countries concerned. For the wider population, the familiar SAP story was repeated in Senegal: better macro-economic management generally did not improve conditions for the majority. Agricultural development was an early casualty. The axing of the government's agricultural programme in 1979, then liberalisation measures following devaluation, reduced agricultural investment, extension and input use (Cruise O'Brien, Diop and Diouf 2002). Other rural services were similarly cut. In Dakar, meanwhile, retrenchment of the administration meant drastically fewer public sector jobs. Foucher (2002) finds that, from having recruited an average of $c .3,000$ people per year in the 1960s and 1970s, the civil service only managed to recruit the same number over the whole period of 1981-90. Job scarcity was again exacerbated by demographic growth, which 
meant that more people were chasing these few jobs. This hit the Diola particularly hard as the niche that they had established for themselves, through a particular educational trajectory, was in the lower echelons of public service. The little recruitment now occurring was instead usually the result of natural wastage and hence to more senior posts. In terms of their employment prospects, retrenchment thus hit male migrants worse than women with the latter working outside the public sector, mostly as bonnes. Like the rest of the urban population, such men have been forced to seek new survival strategies in insecure, poorly-paid jobs, increasingly in the informal sector (Cruise O'Brien, Diop and Diouf 2002; Lambert 2002) in line with subregional trends. Female domestic employment is also a difficult existence: girls as young as 10-12 are poorly paid and find themselves exploited by employers, landladies and relatives alike (Cormier 1985; Lambert 2002).

For Lower Casamance villages, increasing outmigration has had two major socioeconomic consequences. The first is the increasing importance of remittances from urban workers, either in cash or in kind (as consumer goods), to those who stay in the region (Cruise O'Brien 2002; Lambert 2002). The second is declining agricultural labour. Men largely undertake migration in the dry season, but if successful jobwise they will stay in town. Women generally return to their villages during the wet season to help with lowland rice cultivation and usually return permanently once married. The supply of salaried urban husbands does not meet demand and the rate of endogamy in rural Diola communities remains high, even if urban employment means that women can now delay marriage (Cormier 1985; Lambert 2002). For both sexes, urban stays have thus become longer and the children of migrants born and raised in town may well not participate in rice cultivation at all (De Jong 2007). Since the 1950s, then, one of the most important parts of the rural workforce - young adults - has increasingly absented itself from Lower Casamance, at least during the dry season and in many cases for longer periods. Paddy rice cultivation has consequently declined 
as the necessary male labour for the maintenance of dykes, and female labour to plant and harvest the crop, have left for the cities in ever-greater numbers (Cormier-Salem 1989; Foucher 2002).

As recorded elsewhere in Africa, though, agricultural production in Lower Casamance has adapted to the changed circumstances brought about by outmigration (e.g. Potts 2010), which have prompted a shift from lowland cultivation to greater emphasis on pre-existing, less labour-intensive activities. These include the harvesting of palm produce, oysters and salt, and fishing on inland waterways; and the cultivation of upland cash crops introduced mostly by Europeans during colonial times such as cashews, mangoes, citrus fruits and most vegetables (Cormier-Salem 1989). Charcoal production is a newer livelihood, serving the urban market (Evans 2003). Cassava and upland cereals, including upland rice, millet and maize, have also become more prominent on the plateaux (Baker 2000): such crops have lower labour requirements than paddy rice as by contrast they are direct-sown and rainfed, even if at times their yields have similarly suffered because of drought. The less salinised edges of lowlands have also sometimes been turned over to dry-season kitchen gardening or to sweet potato cultivation (Evans 2003). In livelihood terms, then, rural-urban migration and its agricultural consequences constitute a move away from subsistence as the principal means of obtaining rice to various combinations of cash cropping, remittances and broader livelihood diversification. In the agricultural sphere, such diversification is, as noted, based largely on the expansion of crops and activities already established in the region, in some cases dating back to prehistory (Cormier-Salem 1989; Linares de Sapir 1971). As Carswell (2002) has observed elsewhere, modern diversification thus needs to be understood in its deeper historical context.

The timeline of this process of de-agrarianisation must be emphasised. The changes in production and livelihoods described were already well underway when chronic drought 
served to accelerate them. Labour shortages had already undermined paddy rice production, particularly from the (notably wetter) 1950s onwards when outmigration from Lower Casamance really became established. The effects of the drought, when it came, were aggravated by the breakdown of dykes neglected because of reduced agricultural labour and, later, by underinvestment in infrastructure due to economic crisis, SAPs and the region's civil conflict. Environmental change is undoubtedly an important factor too but it sits amid this wider context and, crucially, it is historically more recent than the processes that it is sometimes claimed to be driving. Its effects on outmigration and agro-ecological systems are thus the result of complex articulations with pre-existing social processes.

\section{Trope as Fallacy: The Curious Persistence of Agro-Ecological Collapse Explanations in \\ Casamance}

In the face of the evidence supporting the second trope, the first persists nonetheless, simplistically attributing outmigration from Lower Casamance to drought. This is apparent even among local non-governmental organisations (NGOs) and community-based organisations, allegedly closer to social realities on the ground (interviews, Lower Casamance, April-May 2004). Partly as a consequence of their engagement with such groups, it seems, such claims are then reproduced by international NGOs. For example, a report by one London-based NGO operating in Casamance notes, among other trends, a '[d]ecreasing surface area of fertile land [due to salinisation] to distribute to sons, many young people are therefore leaving their villages in search of jobs in the cities' (MRDF 2002: 3). This is perhaps surprising given that a whole literature records continent-wide rural-urban migration and de-agrarianisation (e.g. Bryceson and Jamal 1997; Bryceson, Kay and Mooij 2000; Potts 2010), attributed to a variety of factors but principally driven by economic and social change 
rather than drought. The nature of rural-urban migration by Lower Casamançais also fits a pattern of seasonal or longer-term circular migration that is long established elsewhere in Senegal (Schmitz 1994; Fall 1998), even if in their case it is relatively unusual in its scale and particularly its generality for women as well as men - a phenomenon not seen in the north of the country (Lambert 2002). Similar patterns are reproduced, for men at least, across Sahelian and savanna West Africa (e.g. Hampshire and Randall 1998).

Another contradiction evident in agro-ecological collapse explanations for migration is that Casamance has received migrants as well as lost them. Seasonal and permanent economic migration from northern, Sahelian Senegal is not new. Northern fishermen were present in Casamance from the late 19th century onwards and migration for fishing became significant after the Second World War, as witnessed by whole communities of Toucouleur from the Senegal River Valley who have settled along the Casamance River since the 1940s (Cormier-Salem 1989; Evans 2003). More generally, the post-war period saw increased immigration to Casamance: a 1951 colonial census showed that half of the migrants established in Ziguinchor were from northern Senegal (Lambert 2002). The completion of the Transgambian Highway, then the onset of drought a decade later, served to bring northern farmers, fishermen and traders to Casamance in larger numbers still, even while Casamançais were using the same Highway to head north. This has been a point of conflict at various times and places as nordistes (the term used pejoratively in Casamance for northern Senegalese) have been resented for exploiting locals or dispossessing them by various means from their lands. For example, the large Pata state forest, in Upper Casamance near the Gambian border, has seen its population swollen by mass immigration of Wolof farmers and Toucouleur herders from northern Senegal since the late 1980s (Fanchette 1999). The results have been deforestation - by the end of the 20th century, over half the 73,000 ha forest had already been cleared for groundnut and millet cultivation - and disputes with Fulani herders and others 
already using the forest, leading at times to armed violence (Fanchette 1999; Evans 2003). While this particular scenario concerns upland agriculture and pastoralism rather than lowland cultivation, it further challenges a trope that seeks to explain outmigration in terms of the drought reducing available livelihood opportunities.

The first trope can thus be reasonably characterised as a fallacy: a false argument based on invalid reasoning and, in this case, where evidence exists that clearly contradicts it. The reasons for its persistence therefore merit exploration. Even if such discussion is necessarily speculative, two factors stand out. First, without retreating into essentialistic, 'cultural' explanations, is the symbolic importance of rice and its production among the Diola, particularly (Linares 1992). When the author was conducting livelihood surveys in 2001, some villagers in Lower Casamance would insist that rice production was their most important livelihood activity even where the rice paddies were visibly producing little because of salinisation and the rice being consumed in the village was largely imported (Evans 2003), as indeed has been the case for some decades in much of the region (Cormier-Salem 1989). A reluctance (or denial) on the part of older people to accept social change - that younger people have aspirations beyond staying at home and farming - is also probably a factor. De Jong (2007) describes, for example, how young people are chastised for not returning home from cities often enough or for long enough to contribute to agricultural production and to the economic and social life of the village more widely. The harsh, perhaps unpalatable truth is that they did not hesitate to leave their lands en masse when better economic prospects presented themselves elsewhere, even while retaining symbolic connections with and deep affection for their home villages (Foucher 2002). The fallacy in question, then, contains a strong element of historical myth, rooted in nostalgia for an idealised agrarian past.

It has material implications too, and a second factor important in supporting the fallacy is the role of donors and international NGOs. As already noted, these influential actors 
may be too ready to buy into simplistic but plausible explanations for social change rather than have to grapple with a more nuanced, evidence-based analysis of long-term processes on the ground. The structures of such bodies - with global and regional head offices determining policies that have to encompass great social diversity across the vast spaces that they coverfurther impede understanding of what is really happening at the local level. Studies elsewhere have thus shown that once a particular trope, however fallacious, becomes embedded in regional or global policy thinking, it becomes very hard to dislodge it, particularly where it appears to have a scientific rationale (Leach and Mearns 1996; Stott and Sullivan 2000). In turn, once a trope comes to frame particular development programmes, national actors from government to local NGOs seeking to access funding are all too ready to parrot the concerns that donors wish to hear. The result of this dynamic is that a fallacy may become selfreinforcing as both donor and recipient end up pursuing the same flawed arguments, detached from the evidence base. In this respect and in the context described, though, there is a final twist to the relationship between global concerns and local realities.

\section{Why This All Matters: 'Environmental Refugees' and Misplaced Interventions}

The debate recounted so far sits amid broader contestations about the link between environmental change and migration, and contemporary development interventions that seek to address that link. Key here is the notion of 'environmental refugees', which has antecedents dating back to 1949 but became increasingly prominent in policy discourse in the 1980s and 1990s (Saunders 2000). People displaced by environmental degradation came to be seen in some circles in the immediate post-Cold War era as a threat to global security and were estimated to number 10-25 million worldwide (Black 2001). A relatively quiet period followed through much of the 2000s, when security policies became dominated more by 
concerns about global jihadism. More recently, while such concerns clearly remain strong, forced migration due to environmental change appears resurgent on the agenda of the international community. One international NGO report, rather melodramatically entitled Human tide, argues that '[a]s the effects of climate change join and exacerbate the conflicts, natural disasters and development projects that drive displacement, we fear that an emerging migration crisis will spiral out of control... [O]n current trends, a further 1 billion people will be forced from their homes between now and 2050' (Christian Aid 2007, p. 1). In the run-up to the Copenhagen climate summit (COP15), the British Prime Minister at the time, Gordon Brown, claimed along similar lines that ' $[\mathrm{t}]$ he world would face more conflict fuelled by climate-induced migration if a deal was not agreed' (BBC News 2009).

Critics have long argued, though, that the concept of 'environmental refugees' is simplistic (Black 2001; Saunders 2000). It ignores complex, interlinked, multiple drivers of migration and the often deeper histories involved. There is little empirical evidence for the claims made and figures produced, not least because of problems in analytically isolating the effect of environmental change on migration from many other factors. The concept is also tacitly rooted in neo-Malthusian concerns about overpopulation, particularly that migrants from the developing world will flood (like a 'tide') developed countries - a highly questionable claim as migration for environmental reasons often takes place over relatively short distances. In the face of such concerns and the lack of a strong evidence base, the British Government commissioned a research project, of which Richard Black (whose critique is noted above) was the chair. It attempted to address the issue in a broader context and the first key conclusion of its final report exemplifies its overall approach:

Environmental change will affect migration now and in the future, specifically through its influence on a range of economic, social and political drivers which themselves 
affect migration. However, the range and complexity of the interactions between these drivers means that it will rarely be possible to distinguish individuals for whom environmental factors are the sole driver ("environmental migrants").

(Foresight 2011, p. 9)

In the context of Casamance, such a nuanced view of environmentally-induced migration should point analysis back to the second trope discussed. This is important because, away from high-level policy discussions, a belief in environmental drivers of poverty and migration continue to feed into development interventions there. For example, in Lower and Middle Casamance over the past decade or so, significant donor investment has been evident in anti-salt barrages, partly in the context of 'post-conflict' reconstruction schemes. Larger barrages are placed across the mouths of tributaries to the Casamance River, controlling and at times retaining their flows and preventing estuarine water from penetrating upstream, thereby keeping the water behind them fresh. With hardcore/laterite fill and concrete sluices and bridges, these are substantial pieces of hard engineering, replacing labour-intensive methods of hydrological management with capital-intensive ones. At a smaller scale and more softly engineered, there are also many local barrages constructed of mud and sand, sometimes with wooden reinforcement. These are typically the product of World Food Programme 'Food for Work' or local NGO projects. With these two types of barrage, large areas have thereby in theory been reclaimed for paddy rice cultivation.

However, taking a more critical eye (on the ground or looking at satellite imagery) to these spaces reveals that are rarely completely used. While those near to urban centres like Ziguinchor are more extensively cultivated, some large areas of reclaimed lowland, particularly in Middle Casamance, appear largely devoid of productive activity. Various factors can be cited. In some cases, the barrages have technical design problems that prevent 
them from functioning well (interviews, Djibanar, July 2009; Evans 2009). Even if they do work properly, it still takes a few years before rainwater can leach rice paddies of salts that have accumulated through successive saline water incursions - time during which people will continue to migrate or develop other livelihood activities. Lack of seed rice among communities that have not cultivated rice in recent years has also been identified as an issue, with some interventions distributing this to kickstart production. But arguably the most significant bottleneck remains labour. The paddies are not cultivated because people have better, more remunerative work to do, either in the village or in the city. While, then, a belief that environmental change drives outmigration may justify such interventions, a broader understanding of the de-agrarianised context deeply problematises them.

Circumstances can favour a return to production in some years, though. In 2008, rainfall in Lower Casamance was as abundant as anyone could remember (interviews, September 2008); prices for imported rice had reached a high; and producers were, unusually, receiving support from a high-profile Senegalese government programme. Water levels were high in many rice paddies in the region and people were cultivating large areas. This seems to have been exceptional, however, and such levels of cultivation were not sustained into subsequent years. Still, this example does to some extent challenge the notion of deagrarianisation as a one-way, historical process. It is important to remember that there remains a functioning, agrarian economy in Lower Casamance, albeit based significantly on upland agriculture (particularly orchard crops) and with the livelihoods of most households significantly supplemented by (or indeed largely dependent on) remittances. Other examples from West Africa also show how circumstances can favour an agrarian revival (Fanthorpe and Maconachie 2010). It is worth adding that growth in urbanisation rates has generally been slowing in Francophone West Africa (Beauchemin and Bocquier 2004), as in much of subSaharan Africa (Potts 2010), indicating how deteriorating urban livelihoods may be starting to 
tip the balance of migrants' economic calculations back towards valorising their rural lands. Whatever the case, it is clear that livelihoods are, as ever, dynamically flexible on the basis of a diversity of rural and urban activities and in response to change of all kinds.

\section{Conclusion}

Environmental change and its consequences sound attractive to development actors because they connect readily with global concerns. In such a context, it becomes easier to access funding for interventions premised on battling the effects of such change; trying to reverse historical social processes does not have the same leverage. The agro-ecological collapse trope holds that, with one of the key environmental problems (salinisation) tackled by investment in hydrological infrastructure, people should return to the land, at least if various other factors (such as subsidised agricultural inputs and favourable market conditions) are in place. De-agrarianisation theory and evidence on the ground, however, show that deeperseated processes are at work: a historically-established trajectory of rural-urban migration and ongoing social change, reflected in new expectations among younger people.

How change is perceived and understood has direct consequences, then, for what development programmes are undertaken and how successful they are. The case presented shows how a simplistic model of environmentally-induced migration can lead to erroneous conclusions about multifaceted processes and thus to questionable policy decisions. The development (and increasingly, security) community risks repeating the mistakes of the 20th century, with fallacious tropes about society's relationship with the local environment, particularly when they have a veneer of scientific legitimacy, being used to inform flawed interventions. One-dimensional terms like 'environmental refugees' belie much more complex social dynamics and obscure an understanding of how real people, with agency, have 
long sought to meet their basic needs under the often difficult economic, political, social and (for sure) environmental circumstances of West Africa. Contemporary global environmental change may be a bigger story but the realities of history cannot be denied.

\section{Acknowledgements}

The author warmly thanks the many Casamançais who have helped during fieldwork over the years, most especially his research assistant Oumar Badiane. Research in 2004 was supported financially by the Center for International Climate and Environmental Research - Oslo as part of a collaborative project with the Department of Geography, King's College London, while further fieldwork in 2009-10 was funded by a British Academy Small Research Grant. Both funders are gratefully acknowledged. The chapter benefitted greatly from the constructive criticism given by participants at the 4th International Conference of the Research Group 'Integration and Conflict along the Upper Guinea Coast', held at the Max Planck Institute for Social Anthropology in Halle in September 2012; from the editors' and reviewer's helpful comments; and from careful reading of the final draft by Tamara Hunt (University of Chester).

\section{References}

Agnew, Clive and Ewan W. Anderson (1992), Water Resources in the Arid Realm. London, UK: Routledge.

AJAC-APRAN (2001), Plan du développement local de la communauté rurale de BoutoupaCamaracounda. Local development plan, Ziguinchor, Senegal: Association des jeunes 
agriculteurs de la Casamance - Association pour la promotion rurale de l'arrondissement de Nyassia.

Baker, Kathleen (2000), Indigenous Land Management in West Africa: An Environmental Balancing Act. Oxford, UK: Oxford University Press.

BBC News (2009, October 19), PM warns of climate "catastrophe”. Retrieved from http://news.bbc.co.uk/1/hi/uk/8313672.stm.

Beauchemin, Cris and Philippe Bocquier (2004), "Migration and urbanisation in Francophone West Africa: an overview of the recent empirical evidence," Urban Studies, 41 (11), 22452272.

Black, Richard (2001), Environmental refugees: myth or reality? New Issues in Refugee Research Working Paper no. 34, Geneva, Switzerland: United Nations High Commissioner for Refugees.

Bryceson, Deborah F. (2000), Rural Africa at the crossroads: livelihood practices and policies. Natural Resource Perspectives no. 52, London, UK: Overseas Development Institute.

Bryceson, Deborah F. and Vali Jamal Eds. (1997), Farewell to Farms: De-agrarianisation and Employment in Africa. Aldershot, UK: Ashgate. 
Bryceson, Deborah F., Cristóbal Kay and Jos Mooij Eds. (2000), Disappearing Peasantries? Rural Labour in Africa, Asia and Latin America. London, UK: Intermediate Technology Publications.

Carswell, Grace (2002), “Livelihood diversification: increasing in importance or increasingly recognised? Evidence from southern Ethiopia,” Journal of International Development, 14 (6), 789-804.

Christian Aid (2007) Human Tide: The Real Migration Crisis. London, UK: Christian Aid.

Cormier, Marie-Christine (1985), "Les jeunes diola face à l'exode rural," Cahiers ORSTOM, Série Sciences Humaines, XXI (2-3), 267-273.

Cormier-Salem, Marie-Christine (1989), "Entre terres et eaux: pêche maritime et évolution des systèmes de production en Casamance," Cahiers d'Études Africaines, 115-116 (XXIX-34), 325-338.

Cruise O’Brien, Donal (2002), “Le sens de l'État au Sénégal,” in Le Sénégal Contemporain, Momar-Coumba Diop (Ed.). Paris, France: Karthala, 501-506.

Cruise O'Brien, Donal, Momar-Coumba Diop and Mamadou Diouf (2002), La Construction de l’État au Sénégal. Paris, France: Karthala. 
De Jong, Ferdinand (2007), Masquerades of Modernity: Power and Secrecy in Casamance, Senegal. Edinburgh, UK: Edinburgh University Press for the International African Institute, London.

Dieng, Mbaye (1999), Sursalure et gestion de l'environnement en Moyenne Casamance: le bief Samine-Diana Malari. Master’s dissertation, Saint-Louis, Senegal: Université Gaston Berger.

Evans, Martin (2003), The Casamance, Senegal: 'war economy' or business as usual? PhD thesis, London, UK: King's College London.

Evans, Martin (2009), "Flexibility in return, reconstruction and livelihoods in displaced villages in Casamance, Senegal," GeoJournal, 74 (6), 507-524.

Fairhead, James and Melissa Leach (1996), Misreading the African Landscape: Society and Ecology in a Forest-Savanna Mosaic. Cambridge, UK: Cambridge University Press.

Fairhead, James and Melissa Leach (1998), Reframing Deforestation: Global Analyses and Local Realities: Studies in West Africa. London, UK: Routledge.

Fall, Abdou S. (1998), “Migrants' long-distance relationships and social networks in Dakar," Environment and Urbanization, 10 (1), 135-145. 
Fanchette, Sylvie (1999), Colonisation des terres sylvo-pastorales et conflits fonciers en Haute-Casamance. Drylands Programme Pastoral Land Tenure Series no. 13, London, UK: International Institute for Environment and Development.

Fanthorpe, Richard and Roy Maconachie (2010), "Beyond the 'crisis of youth’? Mining, farming, and civil society in post-war Sierra Leone," African Affairs, 109 (435), 251-272.

Foresight (2011), Migration and global environmental change: future challenges and opportunities. Final project report, London, UK: Government Office for Science.

Foucher, Vincent (2002), “Les « évolués », la migration, l’école: pour une nouvelle interprétation de la naissance du nationalisme casamançais," in Le Sénégal Contemporain, Momar-Coumba Diop (Ed.). Paris, France: Karthala, 375-424.

Grainger, Alan (1990), The Threatening Desert: Controlling Desertification. London, UK: Earthscan.

Hampshire, Kate and Sara Randall (1999), "Seasonal labour migration strategies in the Sahel: coping with poverty or optimising security?,” International Journal of Population Geography $5(5), 367-385$.

Hopkins, Antony G. (1973), An Economic History of West Africa. London, UK: Longman. 
Hulme, Mike (1999), "Climate change within the period of meteorological records," in The Physical Geography of Africa, William M. Adams, Andrew S. Goudie and Antony R. Orme (Eds.). Oxford, UK: Oxford University Press, 88-102.

Lambert, Michael C. (2002), Longing for Exile: Migration and the Making of a Translocal Community in Senegal, West Africa. Portsmouth, NH, USA: Heinemann

Leach, Melissa and Robin Mearns Eds. (1996), The Lie of the Land: Challenging Received Wisdom on the African Environment. Oxford, UK: James Currey for the International African Institute, London.

Linares de Sapir, Olga F. (1971), "Shell middens of Lower Casamance and problems of Diola protohistory," West African Journal of Archaeology, 1, 23-54.

Linares, Olga F. (1992), Power, Prayer and Production: The Jola of Casamance, Senegal. Cambridge, UK: Cambridge University Press.

MRDF (2002), The Casamance, Senegal. NGO report, London, UK: Methodist Relief and Development Fund.

Pélissier, Paul (1983), "La Casamance,” in Atlas du Sénégal, 2ème édition, Paul Pélissier (Ed.). Paris, France: Jeune Afrique, 54-57.

Potts, Deborah (2010), Circular Migration in Zimbabwe and Contemporary Sub-Saharan Africa. Oxford, UK: James Currey. 
Reuveny, Rafael (2007), “Climate change-induced migration and violent conflict," Political Geography 26 (6), 656-673.

Sar, Moustapha (1977), "Regional planning in Senegal,” in Regional Planning and National Development in Tropical Africa, Akin L. Mabogunje and Adetoye Faniran (Eds.). Ibadan, Nigeria: Ibadan University Press, 60-67.

Saunders, Patricia (2000), "Environmental refugees: the origins of a construct," in Political Ecology: Science, Myth and Power, Philip Stott and Sian Sullivan (Eds.). London, UK: Arnold, 218-246.

Schmitz, Jean (1994), “Cités noires: les républiques villageoises du Fuuta Tooro (Vallée du fleuve Sénégal)," Cahiers d'Études Africaines, 133-135 (XXXIV-1-3), 419-460.

Stott, Philip and Sian Sullivan Eds. (2000), Political Ecology: Science, Myth and Power. London, UK: Arnold.

Swift, Jeremy (1996), "Desertification: narratives, winners \& losers," in The Lie of the Land: Challenging Received Wisdom on the African Environment, Melissa Leach and Robin Mearns (Eds.). Oxford, UK: James Currey for the International African Institute, 73-90. 